\title{
Tension pneumothorax as a severe complication of endobronchial ultrasound-guided transbronchial fine needle aspiration of mediastinal lymph nodes
}

\author{
Maciej Gnass ${ }^{1}$, Artur Szlubowski ${ }^{1}$, Tomasz Gil${ }^{2}$, Piotr Kocoń ${ }^{2}$, Mirosław Ziętkiewicz ${ }^{3}$, \\ Magdalena Twardowska³, Jarosław Kużdżat ${ }^{2}$
}

${ }^{1}$ Independent Endoscopy Unit, John Paul II Specialist Hospital in Krakow, Poland

${ }^{2}$ Clinical Department of the Clinic of Thoracic Surgery, Collegium Medicum of the Jagiellonian University, John Paul II Specialist Hospital in Krakow, Poland

${ }^{3}$ Department of Anesthesiology and Intensive Pulmonary Care, John Paul II Specialist Hospital in Krakow, Poland

Kardiochirurgia i Torakochirurgia Polska 2015; 12 (4): 359-362

\begin{abstract}
This article presents a case report of a patient suffering from bullous emphysema and chronic obstructive pulmonary disease, who was diagnosed with tension pneumothorax after undergoing endobronchial ultrasound-guided transbronchial needle aspiration (EBUS-TBNA).

Tension pneumothorax is a severe but rare complication of EBUS-TBNA. It can result from lung injury caused by the biopsy needle or, in patients suffering from bullous emphysema, from spontaneous rupture of an emphysematous bulla resulting from increased pressure in the chest cavity during cough caused by bronchofiberoscope insertion. The authors emphasize that patients should be carefully monitored after the biopsy, and, in the case of complications, provided with treatment immediately in proper hospital conditions. Patients burdened with a high risk of complications should be identified before the procedure and monitored with extreme care after its completion.

Key words: tension pneumothorax, bronchofiberoscopy, endobronchial ultrasound-guided transbronchial needle aspiration (EBUS-TBNA).
\end{abstract}

\section{Introduction}

The most widely accepted method of minimally invasive diagnostics for mediastinal lymph node enlargement in the course of lung cancer and sarcoidosis is endobronchial ultrasonography (EBUS), which has been in use for over a decade [1, 2]. In cases in which imaging of the posterior mediastinum and the left adrenal gland is required, the examination can be supplemented with endoesophageal

\section{Streszczenie}

W pracy zaprezentowano opis przypadku odmy opłucnowej prężnej, która wystąpiła u pacjenta z rozedmą pęcherzową i przewlekłą obturacyjną chorobą płuc po wykonaniu przezoskrzelowej biopsji aspiracyjnej cienkoigłowej węzłów chłonnych śródpiersia wykonanej pod kontrolą ultrasonografii wewnątrzoskrzelowej (endobronchial ultrasound-guided transbronchial needle aspiration - EBUS-TBNA). Odma prężna jest ciężkim, jednak rzadkim powikłaniem EBUS-TBNA. Może być wynikiem zarówno uszkodzenia płuca igłą biopsyjną, jak i u pacjentów z rozedmą pęcherzową - samoistnego pęknięcia pęcherza rozedmowego na skutek wzrostu ciśnienia w klatce piersiowej podczas kaszlu wywołanego wprowadzeniem bronchofiberoskopu do drzewa oskrzelowego. Autorzy zwracają uwagę na konieczność ścisłego monitorowania chorych po wykonaniu biopsji oraz zapewnienia dostępu do natychmiastowego leczenia powikłań w warunkach szpitalnych. Pacjentów o zwiększonym ryzyku powikłań należy zidentyfikować przed przystąpieniem do zabiegu i szczególnie uważnie monitorować po jego wykonaniu.

Słowa kluczowe: odma prężna, bronchofiberoskopia, przezoskrzelowa biopsja aspiracyjna cienkoigłowa pod kontrolą ultrasonografii wewnątrzoskrzelowej (EBUS-TBNA).

ultrasonography (EUS) [3]. The joint examination, known as combined ultrasonography (CUS), was initially performed using two devices (a bronchofiberoscope and a gastrofiberoscope) equipped with a sector ultrasound transducer. At present, the most popular method is CUSb, which employs a single bronchofiberoscope; this significantly reduces the duration of the examination and the cost associated with the procedure without having a significant impact on 
the diagnostic efficacy of the method $[4,5]$. The most important advantage of the described diagnostic methods is that needle aspiration can be performed in real time under ultrasound control, providing cytological material for histopathological assessment.

The combined ultrasound-needle aspiration (CUSb$\mathrm{NA}$ ) examination is considered relatively safe and is well tolerated by the patients when short-term analgesia and sedation is administered intravenously $[2,5]$. The relevant complications that are most often described in the literature are infectious complications after endobronchial ultrasound-guided transbronchial needle aspiration (EBUSTBNA) [6, 7].

The incidence of EBUS-TBNA complications in the largest survey study conducted by the Japan Society for Respiratory Endoscopy was estimated at $1.23 \%$; the most common complications were harmless self-limiting bleeding $(0.68 \%)$ and infectious complications $(0.14 \%)$. The latter included mediastinitis, pneumonia, pericarditis, infections after cyst puncture, and even sepsis [8]. Pneumothorax as a complication of EBUS-TBNA was diagnosed in only 2 patients out of over seven thousand examined (0.03\%), and only one of these patients required pleural drainage [8]. In the largest American study, ACCP AQuIRE (American College of Chest Physicians Quality Improvement Registry, Education), which included 1317 patients, the incidence of complications after EBUS-TBNA was 1.44\%; pneumothorax occurred in as many as 7 patients, in most cases after lung biopsy with the EBUS-TBNA method [9]. One case of pneumothorax has been described as a major complication after CUS-NA performed during the only randomized study comparing the efficacy of echosonography with mediastinoscopy [10].

\section{Case study}

The 63-year-old male patient with diagnosis of infiltrative lesions of the left lung and hilum as well as mediastinal lymphadenopathy (Fig. 1) and suspicion of hyperplasia

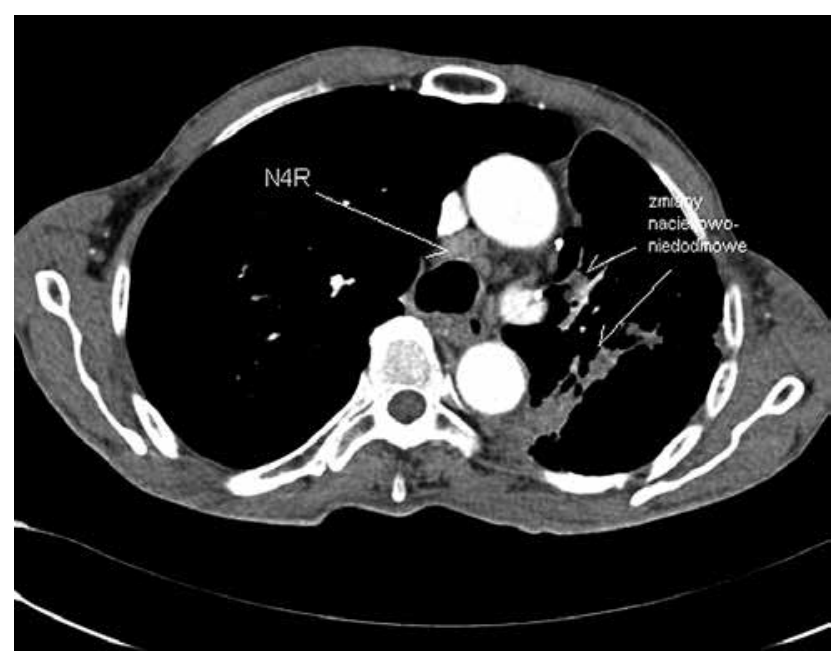

Fig. 1. Chest computed tomography (CT) (mediastinal window) enlarged mediastinal lymph nodes (N4R) and infiltrative-atelectatic lesions of the left lung and hilum was admitted to the Clinical Department of Thoracic Surgery of the John Paul II Specialist Hospital in Krakow for histopathological verification. The patient's medical history included chronic obstructive pulmonary disease (COPD) and bullous emphysema of both lungs; seven years earlier, he underwent left-sided upper lobectomy due to the presence of non-neoplastic cysts. Infiltration of the left hilar area and the mediastinal lymph node packets were revealed by a chest computed tomography (CT) scan performed in July, 2013 at the Department of Pulmonology, where the patient was hospitalized due to COPD exacerbation with bronchogenic inflammation of the right lung. In the course of further diagnostics, an out-patient positron emission tomography-computed tomography (PET-CT) examination was performed, revealing moderate metabolic stimulation (SUV 3.5-6.2) of the infiltrative-atelectatic lesions of the left lung and mediastinal lymph nodes: group 4R (right lower paratracheal) and group 7 (subcarinal).

The CUSb examination performed in August, 2013 confirmed the presence of perihilar infiltration of the lower lobe of the left lung (visible on both the EBUS and the EUS image). However, due to the fibrosis and rotation of the lower lung bronchial openings, EBUS-TBNA was not performed as the lesion was outside the reach of the biopsy needle. Group 7 lymph node biopsy was performed, and the procedure was uneventful. Cytological assessment did not demonstrate the presence of neoplastic cells.

In September 2013, the patient was readmitted to the Clinical Department of Chest Surgery due to persisting radiological changes in the left lung and mediastinal lymph node enlargement. The patient again underwent a CUSbNA examination, and material for cytological investigation was obtained from the lymph nodes (group 7 - with EUSFNA, and group 4R - with EBUS-TBNA; Fig. 2).

During the examination and immediately after, the patient reported no complaints. No saturation drop was observed in pulse oximetry. After the examination, the patient was transferred from the Endoscopy Unit to the ward.

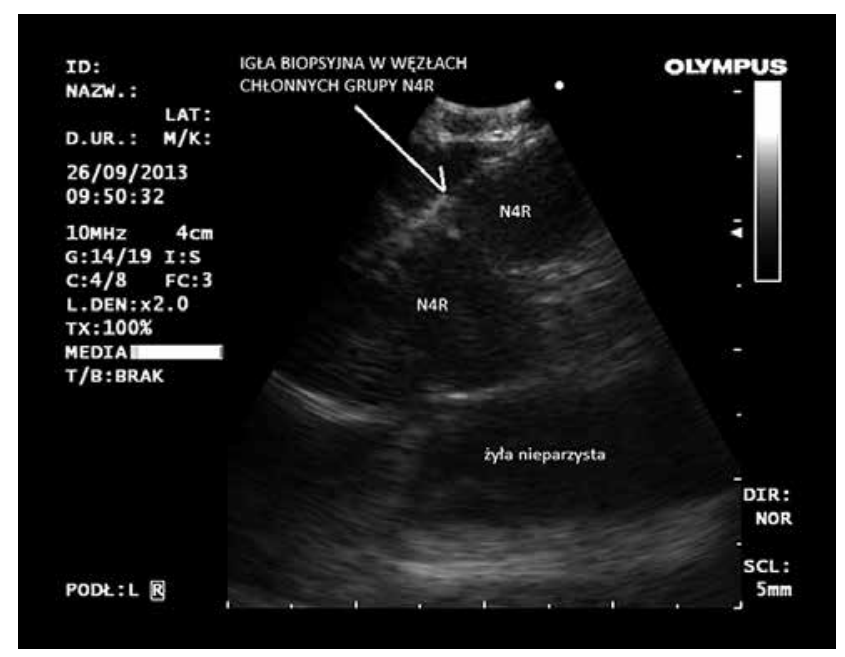

Fig. 2. Endobronchial ultrasound-guided transbronchial needle aspiration (EBUS-TBNA) - aspiration biopsy of group 4R lymph nodes 


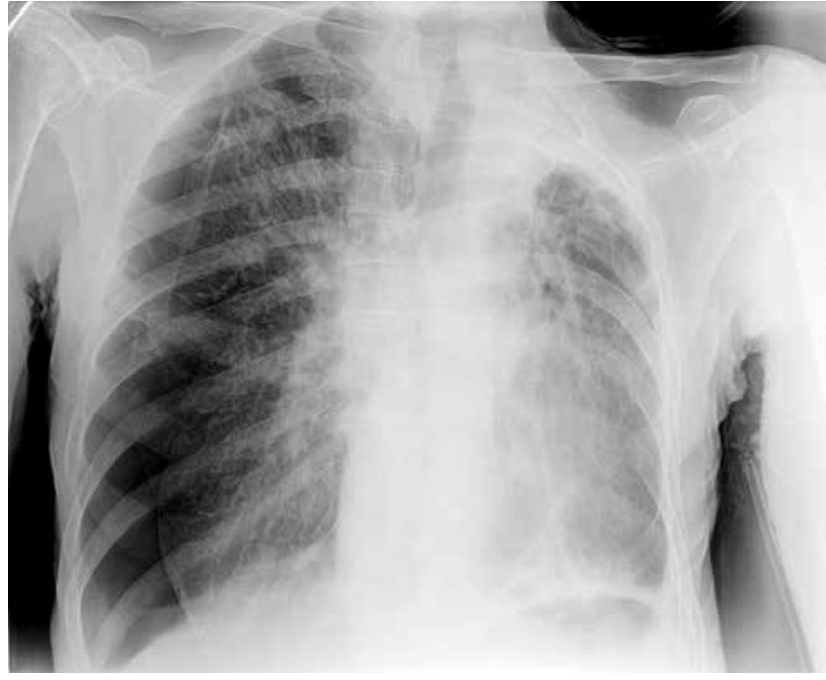

Fig. 3. X-ray of the chest - right-sided tension pneumothorax

Approximately 30 min after the end of the endoscopic examination, the patient reported sudden pain in the right half of the chest, accompanied by dyspnea. Physical examination revealed tachypnea, no alveolar murmur above the right side of the chest, and tympanitic resonance. The obtained chest radiogram visualized right-sided pneumothorax and mediastinal displacement to the left (Fig. 3). During the diagnostic examinations, the patient's condition deteriorated: he lost consciousness, his arterial blood pressure dropped to $50 / 20 \mathrm{mmHg}$, and his heart rate slowed to 30 bpm (bradycardia). A drain was immediately inserted into the right pleural cavity, and suction drainage was applied, resulting in swift improvement of the patient's condition. Further radiograms confirmed full expansion of the right lung (Fig. 4). The drain was removed on the $4^{\text {th }}$ day; on the next day, the patient was discharged home in good general condition.

\section{Discussion}

Methods of endoscopic echosonography are safe for patients $[1-5,10]$. According to the largest publications, the incidence of all complications is approximately $1-1.5 \%[8,9]$. Most major complications are associated with the needle aspiration [9]. The most common ones include inflammatory complications (mediastinitis, pneumonia, pericarditis), bleeding complications (bleeding into the lumen of the bronchial tree or into the mediastinum), pneumothorax, and mediastinal emphysema. Most often, the complications pose no threat to the patient's life [6-10].

Pneumothorax may result from injury of the pulmonary pleura of a previously unchanged lung or from an accidental puncture of an emphysematous bulla during the needle biopsy. In patients with bullous emphysema, this complication may occur as a result of a spontaneous rupture of an emphysematous bulla, caused by an increase of pressure in the chest resulting from strenuous cough during bronchofiberoscopy.

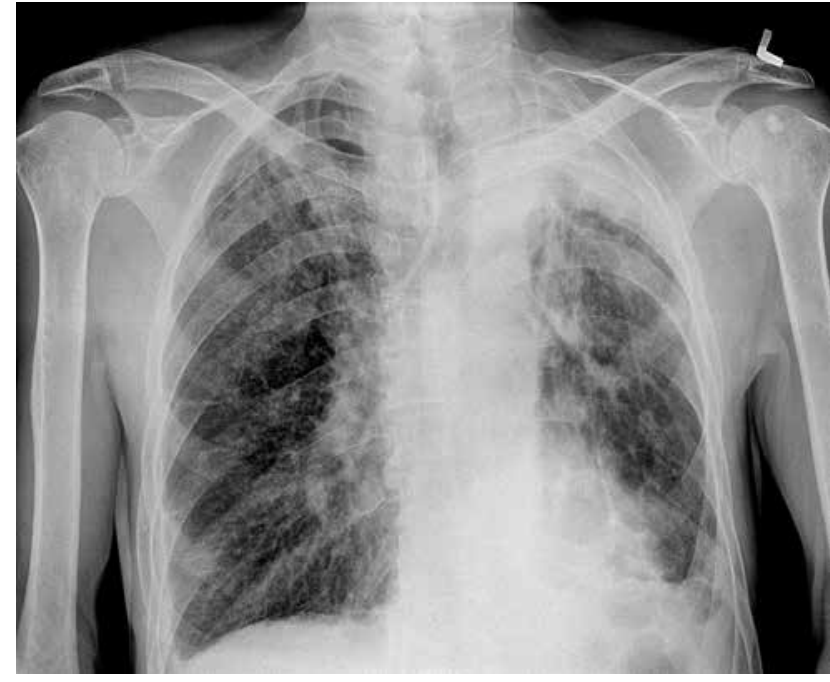

Fig. 4. X-ray of the chest after removal of the drain - normally expanded lungs

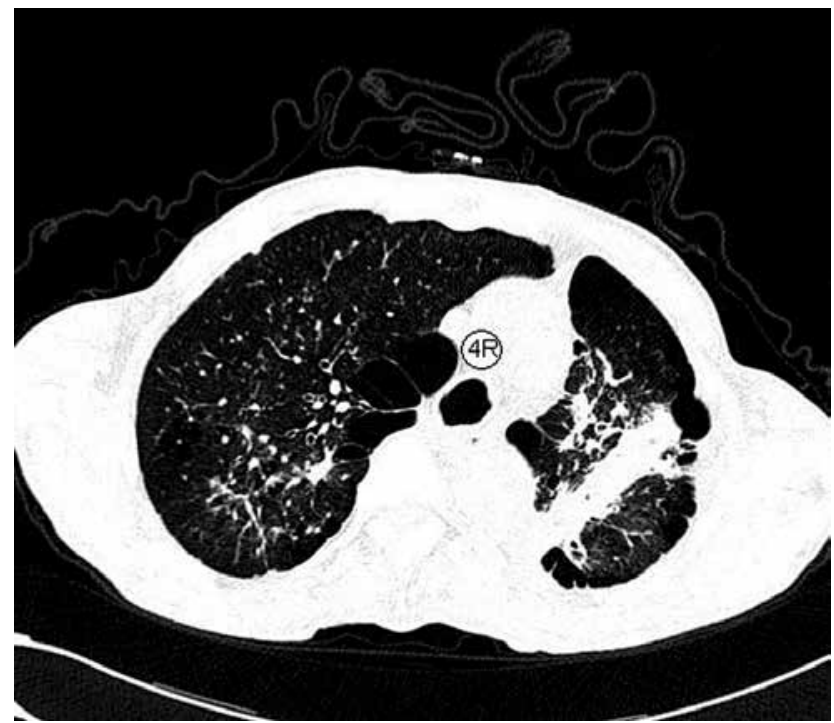

Fig. 5. Chest tomography (pulmonary window) - emphysematous bullae adhering to the mediastinal lymph nodes

In the present case, the emphysematous bullae adhered directly to the group 4 lymph nodes biopsied during the second CUSb examination, as shown in Figure 5.

The management strategy in view of diagnosed emphysema depends on the lesion's size and the clinical condition of the patient. If the emphysema is small, and the patient's condition is stable, it is sufficient to employ passive oxygen therapy and monitor the size of the emphysematous chamber. Patients with larger emphysemas require suction drainage of the pleural cavity. In the case of tension pneumothorax, introducing a drain into the pleural cavity is a life-saving procedure and must be performed immediately after diagnosis.

Pneumothorax is a particularly rare complication after echosonography [8-10]. Nonetheless, the possibility of its occurrence must be taken into account; patients should be monitored during the first hours after the procedure, and 
their complaints, such as chest pain, dyspnea, or cough, should be addressed immediately. Delaying the diagnosis and, consequently, the implementation of appropriate treatment, may have dire consequences for the patient. Therefore, it appears justified to monitor patients after EBUS/EUS procedures for at least 24 hours in order to minimize the risk to their lives. It is also of paramount importance to identify patients burdened with a higher risk of complications (e.g. with advanced emphysema, as in the case of the present patient) before the procedure and to carefully monitor such patients after the procedure is completed.

\section{Disclosure}

Authors report no conflict of interest.

\section{References}

1. Herth FJF, Eberhardt R, Vilmann P, Krasnik M, Ernst A. Real-time endobronchial ultrasound guided transbronchial needle aspiration for sampling mediastinal lymph nodes. Thorax 2006; 61: 795-798.

2. von Bartheld MB, Dekkers OM, Szlubowski A, Eberhardt R, Herth FJ, in 't Veen JC, de Jong YP, van der Heijden EH, Tournoy KG, Claussen M, van den Blink B, Shah PL, Zoumot Z, Clementsen P, Porsbjerg C, Mauad T, Bernardi FD, van Zwet EW, Rabe KF, Annema JT. Endosonography vs conventional bronchoscopy for the diagnosis of sarcoidosis: the GRANULOMA randomized clinical trial. JAMA 2013; 309: 2457-2464.

3. Vilmann P, Krasnik M, Larsen SS, Jacobsen GK, Clementsen P. Transesophageal endoscopic ultrasound-guided fine-needle aspiration (EUS-FNA) and endobronchial ultrasound-guided transbronchial needle aspiration (EBUS-
TBNA) biopsy: a combined approach in the evaluation of mediastinal lesions. Endoscopy 2005; 37: 833-839.

4. Herth FJ, Krasnik M, Kahn N, Eberhardt R, Ernst A. Combined endoscopicendobronchial ultrasound-guided fine-needle aspiration of mediastinal lymph nodes through a single bronchoscope in 150 patients with suspected lung cancer. Chest 2010; 138: 790-794.

5. Szlubowski A, Soja J, Kocoń P, Talar P, Czajkowski W, Rudnicka-Sosin L, Ćmiel A, Kużdżat J. A comparison of the combined ultrasound of the mediastinum by use of a single ultrasound bronchoscope versus ultrasound bronchoscope plus ultrasound gastroscope in lung cancer staging: a prospective trial. Interact Cardiovasc Thorac Surg 2012; 15: 442-446.

6. Huang CT, Chen CY, Ho CC, Yu CJ. A rare constellation of empyema, lung abscess, and mediastinal abscess as a complication of endobronchial ultrasound-guided transbronchial needle aspiration. Eur J Cardiothorac Surg 2011; 40: 264-265.

7. Moffatt-Bruce SD, Ross P. Mediastinal abscess after endobronchial ultrasound with transbronchial needle aspiration: a case report. J Cardiothorac Surg 2010; 5: 33.

8. Asano F, Aoe M, Ohsaki Y, Okada Y, Sasada S, Sato S, Suzuki E, Semba H, Fukuoka K, Fujino S, Ohmori K. Complications associated with endobronchial ultrasound-guided transbronchial needle aspiration: a nationwide survey by the Japan Society for Respiratory Endoscopy. Respir Res 2013; 14: 50.

9. Eapen GA, Shah AM, Lei X, Jimenez CA, Morice RC, Yarmus L, Filner J, Ray C, Michaud G, Greenhill SR, Sarkiss M, Casal R, Rice D, Ost DE; American College of Chest Physicians Quality Improvement Registry, Education. Complications, consequences, and practice patterns of endobronchial ultrasoundguided transbronchial needle aspiration: Results of the AQuIRE registry. Chest 2013; 143: 1044-1053.

10. Annema JT, van Meerbeeck JP, Rintoul RC, Dooms C, Deschepper E, Dekkers OM, De Leyn P, Braun J, Carroll NR, Praet M, de Ryck F, Vansteenkiste J,Vermassen F, Versteegh MI, Veseliç M, Nicholson AG, Rabe KF, Tournoy KG. Mediastinoscopy vs endosonography for mediastinal nodal staging of lung cancer: a randomized trial. JAMA 2010; 304: 2245-2252. 